\title{
Effective Leadership in Organization
}

\author{
Bhumika Shah
}

\begin{abstract}
In this article, different factors that impact organization leadership has been described, and how it effects leadership effectiveness is examined. Different sixty articles have been studied to find integrative model on effective leadership in organization. The aim of the model is to study all the important aspects that builds effective leadership in the organization.
\end{abstract}

Index Terms-Effective Leadership; Leadership Behavior; Leadership Ethics; Leadership Styles.

\section{INTRODUCTION}

Leadership is natural and spontaneous process that gives meaning to unstructured mechanism of the organization [1].Its proposed growth of the organization can be best achieved by working for common goal and capacity of leaders to make commitments [2]. It is not mandatory to have leadership traits at upper levels of organization, it can exercised at any hierarchical level of organization [3]. Leadership is necessary in the organization for innovation, creating enthusiasm, creating focus, motivating and aligning people [4].

\section{RESEARCH METHOD}

In the research presented here the focus is on combining the most important "previously established studies and concepts" that I have identified in the academic literature based on which I provide a synthesis that "advances our understanding" [5]. In this study I identified $t$ most important variables that help in the current business or organizational situation to build leadership, to accomplish a competitive advantage. My examination approach joins the "interpretive paradigm" in which a rich depiction of each factor in our present association setting is built up [6].

In aim of the study is to create hypothesis on leadership effectiveness, which is coordinated, reliable, conceivable, and sufficiently clear [7]. It is a comprehensive literature review on factors effecting effective leadership in business.

Different articles have been reviewed in relevant journals to create theoretical foundation of this paper.

The commitment of the investigation is planned to survey and compress the hypothetical and exact information that ought to rouse new dialogs and headings for additionally explore movement [8].

\section{DISCUSSION}

\section{A. Effective Leadership in Business}

Leader inspires confidence and support among people ,who aspires to achieve organizational goals [9]. leadership expands the extent of the life span and achievement of a business. Making and growing a business, especially for a new business or one that has as its essential concentration on technical advances, requires the help of leaders and managers [10]. Leader influence his team members to work for a common goal [11]. It is believed that, different situations demands for different leadership styles and leader should know which style to use [12]. Effective leadership play vital role in success of virtual teams at both team and individual level [13] and leaders traits are positively connected to small business [14]. Wise pioneers move from a restricted concentrate on operation and methodology to a more all-encompassing point of view and reacts to outside occasions with wisdom, adaptability, and validness [15].

Management and leadership though sound similar but they are different, leadership is seen to be a part of management and they are both important for the organization [16]. Manager of the organization faces complexity and leader makes changes, but both of them take decisions about organization plans and building relationship among people [17]. Management is important for leadership effectiveness [18]. It is important for top management to have leadership qualities to motivate ,inspire subordinates, resolve conflicts between people and for power sharing at different levels in organization [19]. In innovation administration, top managers will be more successful with empowering leadership, middle managers will be more viable with directive or supportive authority and supervisors will be best, if they stay away from supportive leadership [20].

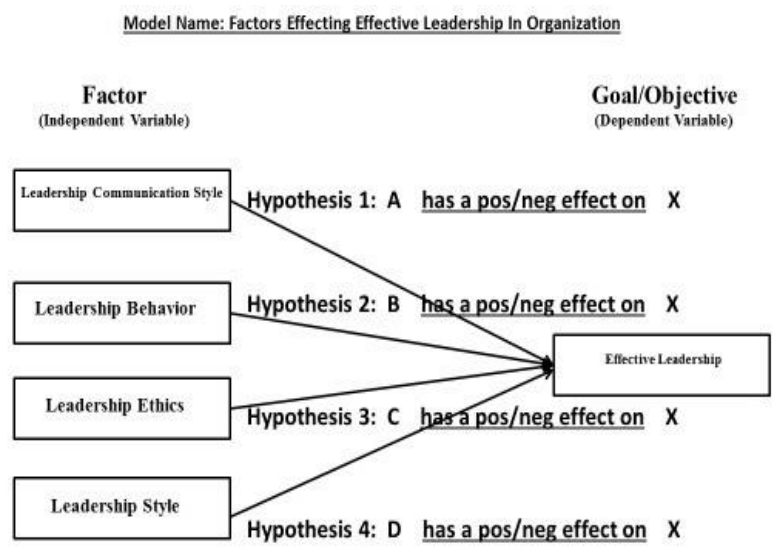

Fig. 1. Factors Affecting Effective Leadership in Organization 


\section{B. Communication Style}

In the different researches it has been found that social and communication skills contribute to leader's emergence and effectiveness [21]. Leader should be aware of the factors that focus on relationships, symbolic communication, body language, and cognitive complexity for a better, more effective communication strategy [22]. Moreover, verbal and written communication directly relate to team outcomes and sometimes also customer's satisfaction [23]. It has been seen that leader's communication style boost worker's motivation and performance, that in turn gives dedicated workforce to the organization [24]. It has also be seen that motivational language of leader helps the team members to come with more innovation [25]. In the study it is found that $10 \%$ increase in leader's motivational language, increases $5 \%$ employees intention to stay [26]. There are four fundamental communication styles: Analytical, Intuitive, Functional and Personal [27].

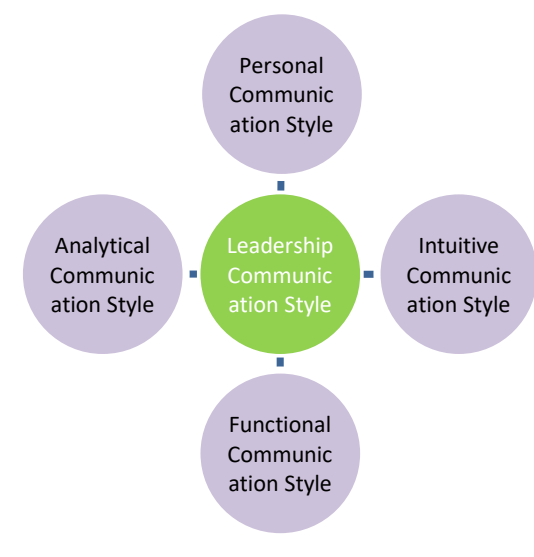

Fig. 2. Leadership Communication Style [28]

\section{1) Analytical leadership Communication}

Analytical leadership is based on data and facts, it favors logic and accuracy. Every action is taken by some thoughtful consideration and follows some rational process [29].

\section{2) Intuitive leadership Communication}

Intuitive leadership communication is based on intuition and instinct of leader. Though it does not fit any scientific model but are important part of leadership communication. It is said that suggestions or actions that comes out of intuition are clear, focused and are comes from alert and conscious mind. This style is commonly found in top levels of organizations [30].

\section{3) Functional leadership communication}

In this style, fundamental occupation is to do, or complete, whatever needed to complete group job. Inside this approach the pioneer is compelling to the extent that he/she guarantees that all capacities basic to undertaking and group upkeep are finished [31].

\section{4) Personal Leadership Communication}

Personal communication style is open and straightforward, leaders can practice this style to get nearer to subordinates, construct trust, advance exchange, connect with workers, and adjust their correspondence to organization planning [32].

\section{Leadership Behavior}

For effectiveness in leadership, traits and skills should be transformed into behavior of leader [33]. In one research conducted by scholars at Ohio university, it was found that two important factors of leadership are consideration and initiating factor [34] and both the factors together contribute towards leader's effectiveness [35].

Consideration factor of leader focusses towards feeling of warmth, support, friendliness and trust among subordinates ,Initiating structure focusses towards assigning tasks, specifying procedures, scheduling work, clarifying expectations and establishing realistic goals [36]. Consideration provides employee satisfaction and initiating factor contributes to employee performance [37]. From the study it has been analyzed that leader's consideration and initiating factor contribute to subordinates satisfaction [38]. Leader with high score in initiating factor will pay more attention towards planning the task, communicating and scheduling job and new ideas, on the other hand leader with high score in consideration, will talk more about employee's trust, feeling, rest and job satisfaction [39].

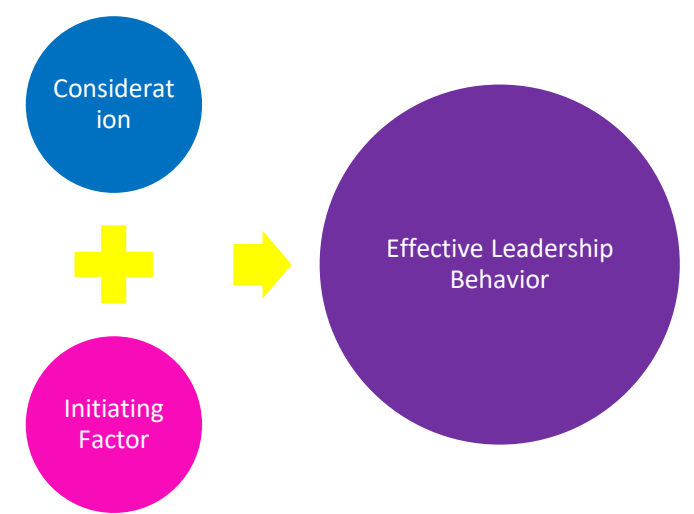

Fig. 3. Factors Determining Effective Leadership Behavior

\section{1) Consideration}

Consideration factor of leader focusses towards feeling of warmth, support, friendliness and trust among subordinates. Leader with high score in consideration, will talk more about employee's trust ,feeling, rest and job satisfaction [39].

\section{2) Initiating Factor}

Initiating structure focusses towards assigning tasks, specifying procedures, scheduling work, clarifying expectations and establishing realistic goals [36].leader with high score in initiating factor will pay more attention towards planning the task, communicating and scheduling job and new ideas [39].

\section{Leadership Ethics}

Ethical leader is believed to influence the employee and organizational behavior [40]. Ethical leadership is important to ensure that the actions, and values of leadership ethics consists of right, wrong, great, insidious, righteousness, obligation, commitment, rights, equity, decency, and so on in human associations with each other and other living things [41]. An effective ethical leader guarantee that his subordinates perceive him or her as an ethical person who 
can be trusted and respected, who treats everyone equally [42]. If leader will be ethical, his team members will also work in ethical direction for the organization [43]. Ethical leadership promotes positivity and morality in the team, to support building individuals, company and community [44]. When the impact of the company leader upon the company image, identity and prestige is considered, it becomes important to create competitive strategies with codes of ethics [45].

\section{1) Fairness}

Fairness in the organization acts as a driving force that guides people to work for a common goal and motivates them to come into the agreement to work [46]. It is studied that fairness in the workplace builds trust of the employees in the organization [47].

\section{2) Power Sharing}

Power sharing, appropriately organized, can support balance and debilitate radicalism. Power sharing builds stability and reduce violence [48].

\section{3) People Orientation}

Individuals situated administration works since individual representatives and colleagues esteem compassion and welcome a bona fide concentrate on their prosperity [49].

\section{4) Integrity}

Integrity means adherence to moral and moral standards; soundness of good character; trustworthiness; the condition of being entire, whole, or undiminished; a sound, healthy, or consummate condition [50].

\section{5) Ethical Guidance}

leaders ought to be a key origin of ethical direction for workers. Most workers look outside themselves to some noteworthy others for moral direction. Consequently, in the work environment, leaders ought to be a central source for such direction [51].

\section{6) Concern for Sustainability}

We set that organizations are perplexing versatile frameworks working inside more extensive complex versatile frameworks, making the issue of translating just how an association is to be manageable, a phenomenal request on leaders. Henceforth, leadership for manageability requires leaders of unprecedented capacities [52].

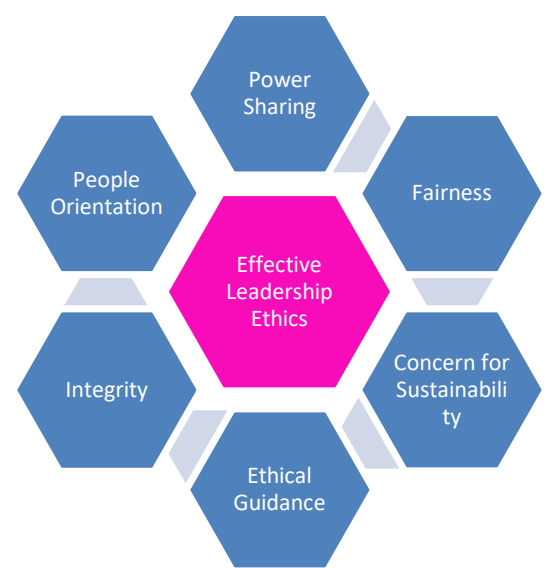

Fig. 4. Effective Leadership Ethics [53]

\section{E. Leadership Styles}

Leader's conduct with his group members reveals regular, predictable, consistent pattern. This pattern characterizes leader's action into leadership styles [33]. It can be characterized into three styles, named as participative, entrepreneurial and autocratic. According to various studies it is believed that there are differences in the leadership styles based on gender. There is no winning formula ,effective leadership comes from all the styles used at right situation [54].Though not universally accepted, it is believed that females possess behavioral oriented style and males have task oriented behavioral style [55].

\section{1) Participative style}

In this leadership style, team leader values team member opinions in decision making. This leadership styles makes employees feel involved and motivated [56].

\section{2) Entrepreneurial style}

In this leadership style, leaders are highly motivated and have strong achievement sense in them. They are highly enthusiastic and creative. They have high vision and act quickly when opportunity arises [57].

3) Autocratic style

In this initiative the leader holds all expert and duty. In this leadership style, leaders settle on choices all alone without consulting subordinates. They achieve choices, convey them to subordinates and expect provoke execution. autocratic workplace does regularly have little or no flexibility [58] behavioral style [55].

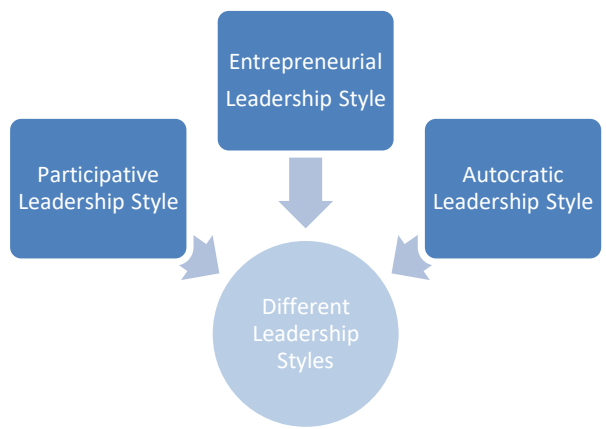

Fig. 5. Different Leadership Styles [59]

\section{RESULTS}

There are many researches and studies on effective leadership, but this topic is still debated and talked about. Effective leadership is a secret ingredient to effective organization performance. It is leader's responsibility to motivate people to work together for common goal. Effective leadership play vital role in success of virtual teams at both team and individual level [13] and leaders traits are positively connected to small business [14].

Different Sixty articles are studied to formulate this model, which shows how leadership communication, leadership ethics, leadership behavior and style effects leaders performance in the organization. 


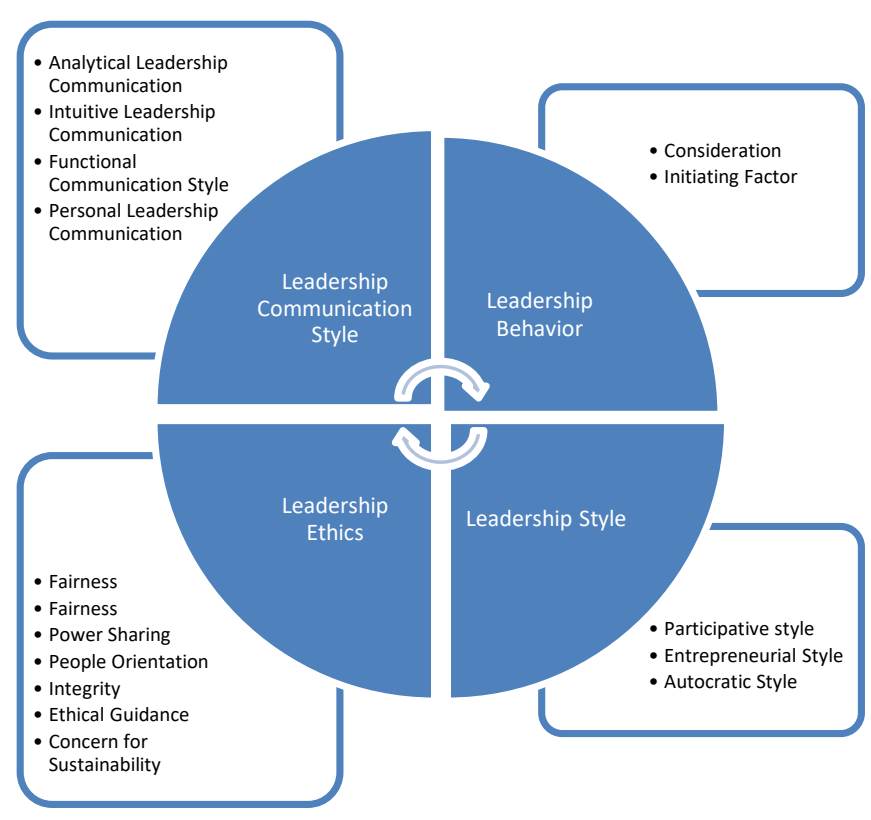

Fig. 6. Effective Leadership Model

\section{CONCLUSION}

The goal of the paper is to develop the model, to understand important factors that makes a leader effective for an organization. The paper studies how different leader's communication, behavior, ethics and styles results leadership effectiveness, and in turn impact performance of the organization.

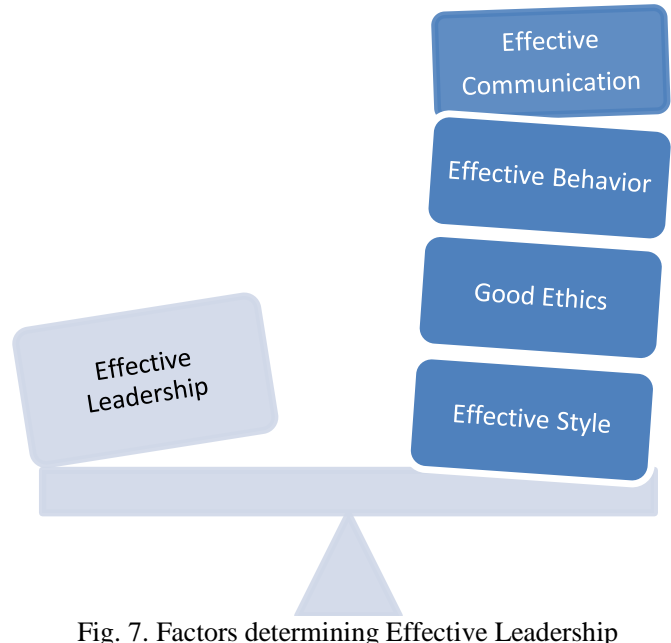

\section{ACKNOWLEDGMENT}

The author would like to thank almighty, for all the wisdom, and courage given to her. The author wants to express her gratitude to her parents Mr. Raj Kumar Shah and Mrs. Preety Shah for supporting her in all the endeavors of life. The author appreciation to Christian Bach, Ph.D., professor at Technology Writing Communication \& Research class in University of Bridgeport, who given understanding, aptitude, and support that enormously helped the research.

\section{REFERENCES}

[1] Smircich, L. and G. Morgan, Leadership: The management of meaning. The Journal of applied behavioral science, 1982. 18(3): p. 257-273.

[2] Alexander, J.M. and J. Buckingham, Common good leadership in business management: an ethical model from the Indian tradition. Business ethics: a European review, 2011. 20(4): p. 317-327.

[3] Minkes, A.L., M.W. Small, and S.R. Chatterjee, Leadership and Business Ethics: Does It Matter? Implications for Management. Journal of Business Ethics, 1999. 20(4): p. 327-335.

[4] Bontas, D., Management and Leadership in business. Economy Transdisciplinarity Cognition, 2012. 15(2): p. 83.

[5] LePine, J.A. and A. Wilcox-King, Developing novel theoretical insight from reviews of existing theory and research. Academy of Management Review, 2010. 35(4): p. 506-509.

[6] Dyer, G.W.J. and A.L. Wilkins, Better stories, not better constructs, to generate better theory: A rejoinder to Eisenhardt. Academy of Management Review, 1991. 16(3): p. 613-619.

[7] Glaser, B.G., The Constant Comparative Method of Qualitative Analysis. Social Problems, 1965. 12(4): p. 436-445.

[8] Sgier, L., Qualitative data analysis. 2012.

[9] DuBrin, A.J., Leadership: Research findings, practice, and skills. 2015: Nelson Education.

[10] Melroy, S. and J.E. Smith, Leadership Defined Businesses International Journal of Modern Engineering Research, 2015. 5(6).

[11] Hoch, J.E. and J.H. Dulebohn, Team personality composition, emergent leadership and shared leadership in virtual teams: A theoretical framework. Human Resource Management Review, 2017. 27(4): p. 678-693.

[12] Xu, J.-H., Leadership theory in clinical practice. Chinese Nursing Research, 2017. 4(4): p. 155-157.

[13] Liao, C., Leadership in virtual teams: A multilevel perspective. Human Resource Management Review, 2017. 27(4): p. 648-659.

[14] Dunne, T.C., et al., The impact of leadership on small business innovativeness. Journal of Business Research, 2016. 69(11): p. 4876 4881.

[15] Pesut, D.J. and S.A. Thompson, Nursing leadership in academic nursing: The wisdom of development and the development of wisdom. Journal of Professional Nursing, 2017.

[16] Liphadzi, M., C.O. Aigbavboa, and W.D. Thwala, A Theoretical Perspective on the Difference between Leadership and Management. Procedia Engineering, 2017. 196(Supplement C): p. 478-482.

[17] Răducan, R. and R. Răducan, Leadership and Management. Procedia - Social and Behavioral Sciences, 2014. 149(Supplement C): p. 808812.

[18] Peck, J.A. and M. Hogue, Acting with the best of intentions... or not: A typology and model of impression management in leadership. The Leadership Quarterly, 2017.

[19] Shao, Z., Y. Feng, and Q. Hu, Impact of top management leadership styles on ERP assimilation and the role of organizational learning. Information \& Management, 2017. 54(7): p. 902-919.

[20] Medcof, J.W., Leadership development: Towards a more systematic approach in technology management. The Journal of High Technology Management Research, 2017. 28(2): p. 167-178.

[21] Riggio, R.E., et al., The role of social and emotional communication skills in leader emergence and effectiveness. Group Dynamics: Theory, Research, and Practice, 2003. 7(2): p. 83.

[22] Halim, N.A.A. and N.A. Razak, Communication Strategies of Women Leaders in Entrepreneurship. Procedia - Social and Behavioral Sciences, 2014. 118(Supplement C): p. 21-28.

[23] Clements, A., et al., The effect of a nurse team leader on communication and leadership in major trauma resuscitations. International Emergency Nursing, 2015. 23(1): p. 3-7.

[24] Mayfield, J. and M. Mayfield, Leader communication strategies critical paths to improving employee commitment. American Business Review, 2002. 20(2): p. 89.

[25] Mayfield, M. and J. Mayfield, The effects of leader communication on worker innovation. American Business Review, 2004. 22(2): p. 46.

[26] Mayfield, J. and M. Mayfield, The effects of leader communication on a worker's intent to stay: An investigation using structural equation modeling. Human Performance, 2007. 20(2): p. 85-102.

[27] Murphy, M., Which Of These 4 Communication Styles Are You? 2015.

[28] Nanus, B., Visionary Leadership: Creating a Compelling Sense of Direction for Your Organization. 1992: ERIC

[29] Higgins, V., Analytical leadership. 2014. 
[30] Khandelwal, P. and A. Taneja, Intuitive Decision Making in Management. Indian Journal of Industrial Relations, 2010. 46(1): p. 150-156.

[31] Burke, C.S., et al., What type of leadership behaviors are functional in teams? A meta-analysis. The Leadership Quarterly, 2006. 17(3): p. 288-307.

[32] Mitchell, D.a., Importance of Communication Skills for Leadership and Management. 2017.

[33] DuBrin, A.J., Principles of leadership. 2010.

[34] Holtz, B.C. and C.M. Harold, Effects of leadership consideration and structure on employee perceptions of justice and counterproductive work behavior. Journal of Organizational Behavior, 2013. 34(4): p. 492-519.

[35] Kerr, S., et al., Toward a contingency theory of leadership based upon the consideration and initiating structure literature. Organizational Behavior and Human Performance, 1974. 12(1): p. 62-82.

[36] Dubrin, A.J., Leadership: Research Findings, Practice, and Skills. Leadership, 2015

[37] Judge, T.A., R.F. Piccolo, and R. Ilies, The forgotten ones? The validity of consideration and initiating structure in leadership research. Journal of applied psychology, 2004. 89: p. 36.

[38] Dobbins, G.H. and S.J. Zaccaro, The effects of group cohesion and leader behavior on subordinate satisfaction. Group \& Organization Studies, 1986. 11(3): p. 203-219.

[39] Korman, A.K., “Consideration," "Initiating Structure," and Organizational Criteria-a Review. Personnel Psychology, 1966. 19(4): p. 349-361.

[40] Özbağ, G.K., The Role of Personality in Leadership: Five Factor Personality Traits and Ethical Leadership. Procedia - Social and Behavioral Sciences, 2016. 235(Supplement C): p. 235-242.

[41] Ciulla, J.B., Leadership ethics: Mapping the territory. Business Ethics Quarterly, 1995. 5(1): p. 5-28.

[42] Cels, S., Saying sorry: Ethical leadership and the act of public apology. The Leadership Quarterly, 2017. 28(6): p. 759-779.

[43] Stouten, J., et al., Can a leader be seen as too ethical? The curvilinear effects of ethical leadership. The Leadership Quarterly, 2013. 24(5): p. 680-695.

[44] Gallagher, A. and V. Tschudin, Educating for ethical leadership. Nurse Education Today, 2010. 30(3): p. 224-227.

[45] Tutar, H., M. Altınöz, and D. Cakıroğlu, Is ethical leadership and strategic leadership a dilemma? A descriptive survey. Procedia Social and Behavioral Sciences, 2011. 24(Supplement C): p. 13781388
46] Adebayo, D.O., Perceived workplace fairness, transformational leadership and motivation in the Nigeria police: Implications for change. International Journal of Police Science \& Management, 2005. 7(2): p. 110-122.

[47] Pillai, R., C.A. Schriesheim, and E.S. Williams, Fairness perceptions and trust as mediators for transformational and transactional leadership: A two-sample study. Journal of management, 1999. 25(6): p. 897-933.

[48] Sisk, T.D., Power sharing and international mediation in ethnic conflicts. 1996: US Institute of Peace Press.

[49] Gill, E., What is Relationship-Oriented Leadership? How Supporting People Promotes Teamwork. 2014.

[50] DePersis, D. and A. Lewis, Integrity and Leadership, in Integrity in Organizations. 2013, Springer. p. 347-357.

[51] Brown, M.E., L.K. Treviño, and D.A. Harrison, Ethical leadership: A social learning perspective for construct development and testing. Organizational behavior and human decision processes, 2005. 97(2): p. 117-134.

[52] Metcalf, L. and S. Benn, Leadership for sustainability: An evolution of leadership ability. Journal of Business Ethics, 2013. 112(3): p 369-384.

[53] Hughes, R.L., Leadership: Enhancing the lessons of experience. 1993: ERIC.

[54] Blanken, R., 8 Common Leadership Styles. 2013.

[55] Eagly, A.H. and B.T. Johnson, Gender and leadership style: A metaanalysis. Psychological bulletin, 1990. 108(2): p. 233.

[56] Jhonson, R., Five different types of leadership styles. 2017.

[57] Vromen, A., Entrepreneurial Leadership Styles, in Digital Citizenship and Political Engagement. 2017, Springer. p. 157-189.

[58] Raja, A., 12 Different Types of Leadership Styles. 2017.

[59] Stogdill, R.M., Handbook of leadership: A survey of theory and research. 1974: Free Press.

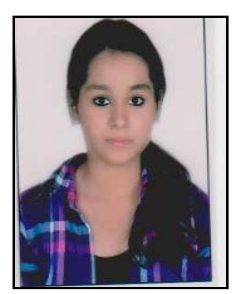

Bhumika Shah was born in Delhi, India in December,04 1994. She obtained her bachelor's degree in electronics and communication from Indraprastha engineering College, Ghaziabad, Uttar Pradesh, India. She is currently pursuing Technology Management from University of Bridgeport, Bridgeport, Connecticut, U.S.A.

She would like to thank her parents Mr. Raj Kumar Shah and Mrs. Preety Shah for supporting her in all the endeavors of life. She is also thankful to her Professor Christian Bach, who helped her during the research. 